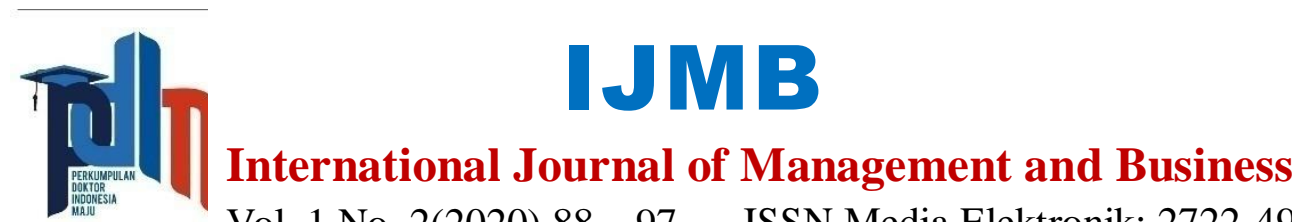

Vol. 1 No. 2(2020) 88 - 97 ISSN Media Elektronik: 2722-4953

\title{
Pengaruh Rasio Keuangan Terhadap Return Saham Pada Perusahaan Lq45 Yang Terdaftar di Bursa Efek Indonesia
}

\author{
RomlinaSianipar $^{1}$, Syahril Effendi ${ }^{2}$ \\ ${ }^{1}$ Mahasiswa Program Studi Akuntansi,Universitas Putera Batam \\ ${ }^{2}$ Dosen Program Studi Akuntansi, Universitas Putera Batam \\ e-mail:pb130810348@upbatam.ac.id
}

\begin{abstract}
The purpose of this study was to determine the Effect of Financial Ratios on Stock Returns on LQ45 Companies Listed on the Indonesia Stock Exchange. The independent variables used are Financial Ratios. The dependent variable used is Stock Return. The population in this study is the Current Ratio, Return on Equity, Debt to Equity Ratio, and Stock Return data on LQ45 companies listed on the Indonesia Stock Exchange for 5 years from 2015-2019. The sample in this study is LQ45 companies listed on the Indonesia Stock Exchange (IDX). Data analysis techniques in this study include multiple linear regression. The test results in this study indicate that the Current Ratio variable has no significant effect on Stock Return. From the results of testing the variables above, the Current Ratio shows the calculated $T$ value of $-0.242 T$ value of the table 2.016 with a significance number 0.810>0.05. The Return on Equity variable influences the Stock Return. From the results of testing the variables above, Return on Equity shows that the calculated $T$ value of 2.232> T table value of 2.016 with a significance number of $0.031<0.05$. Debt to Equity Ratio variable has a significant effect on Stock Return. From the results of testing the variables above, Debt to Equity Ratio shows that the calculated T value of 5.923> T table value of 2.016 with a significance number of $0.000<0.05$. Current Ratio, Return on Equity, and Debt to Equity Ratio together have a significant effect on Stock Returns with the number that a significant value of 0,000 $<0.05$ and an $F$ count of $14.498>F$ table of 3.21 .
\end{abstract}

Keywords: Current Ratio, Return on Equity, Debt to Equity Ratio, andStock Return

\begin{abstract}
Abstrak
Tujuan penelitian ini adalah untuk mengetahui Pengaruh Rasio Keuangan terhadap Return Saham pada Perusahaan LQ45 yang Terdaftar di Bursa Efek Indonesia. Variabel independen yang digunakan adalah Rasio Keuangan. Variabel terikat yang digunakan adalah Return Saham. Populasi dalam penelitian ini adalah data Current Ratio, Return on Equity, Debt to Equity Ratio, dan Return Saham pada perusahaan LQ45 yang terdaftar di Bursa Efek Indonesia selama 5 tahun dari tahun 2015-2019. Sampel dalam penelitian ini adalah perusahaan LQ45 yang terdaftar di Bursa Efek Indonesia (BEI). Teknik analisis data dalam penelitian ini meliputi regresi linier berganda. Hasil pengujian dalam penelitian ini menunjukkan bahwa variabel Current Ratio tidak berpengaruh signifikan terhadap Return Saham. Dari hasil pengujian variabel diatas, Current Ratio menunjukkan nilai $\mathrm{T}$ hitung sebesar $-0,242$ nilai $\mathrm{T}$ tabel 2.016 dengan angka signifikansi $0.810>0.05$. Variabel
\end{abstract}

Diterima Redaksi : 25-08-2020 | Selesai Revisi : 31-10-2020 | Diterbitkan Online : 20-11-2020 


\section{RomlinaSianipar ${ }^{1}$, Syahril Effendi ${ }^{2}$}

International Journal of Management and Business (IJMB)Vol.1 No.1 (2020) 88 - 97

Return on Equity mempengaruhi Return Saham. Dari hasil pengujian variabel diatas Return on Equity menunjukkan nilai $\mathrm{T}$ hitung sebesar 2,232> nilai $\mathrm{T}$ tabel sebesar 2,016 dengan angka signifikansi $0,031<0,05$. Variabel Debt to Equity Ratio berpengaruh signifikan terhadap Return Saham. Dari hasil pengujian variabel diatas Debt to Equity Ratio didapatkan nilai T hitung sebesar 5,923> nilai $\mathrm{T}$ tabel sebesar 2,016 dengan angka signifikansi $0,000<0,05$. Current Ratio, Return on Equity, dan Debt to Equity Ratio secara bersama-sama berpengaruh signifikan terhadap Return Saham dengan nilai signifikansi 0,000 <0,05 dan F hitung 14,498> F tabel 3,21.

Kata Kunci: Rasio Lancar, Pengembalian Ekuitas, Rasio Hutang terhadap Ekuitas, daN Pengembalian Saham

(C)2020journalIJMB

\section{Pendahuluan}

Dengan adanya proses pertumbuhan dan penjelasan dengan bursa daha di indonesia memiliki pertumbuhan dari masa ke masa sehingga untuk pertumbuhan perekonomian tersebut sangat dibutuhkan sebuah keseriusan bagi yang mempunyaai usaha agar dapat mengelola usahanya denagn baik dan menjaga proses pertumbuhan modal selama perusahaan terebut berjalan. Seorang pemilik saham harus mampu mengetahui peran perusahaannya di dalam pertumbuhan ekonomi indonesia dengan tujuan agar bisa bersaing dengan perusahaan lain dengan baik demi pertumbuhan perekonomian.

Nisbah kewangan adalah nisbah yang dikira menggunakan penyata kewangan yang berfungsi sebagai alat pengukuran dalam menilai keadaan kewangan dan prestasi syarikat. Nisbah kewangan adalah nombor yang diperoleh dari hasil perbandingan antara satu catatan penyata kewangan dan satu jawatan lain yang mempunyai hubungan yang relevan dan signifikan. Perbandingan boleh dibuat antara satu item dengan item lain dalam satu penyata kewangan atau antara catatan yang ada antara penyata kewangan. Return saham merupakan timbal balik dari investasi yang telah dilakukan investor atau pemegang saham berupa keuntungan yang diperoleh dari jual beli saham di pasar modal [2]. Ketidakpastian dalam menentukan return saham dipengaruhi oleh fluktuasi harga saham yang cepat naik dan turun. Semakin tinggi return yang ditawarkan satu instrument sekuritas maka semakin tinggi kandungan resiko dalam sekuritas bersangkutan (highreturn high risk). Rasio Lancar (Current Ratio) merupakan rasio untuk mengukur kemampuan perusahaan dalam memenuhi kewajiban jangka pendeknya yang segera jatuh tempo dengan menggunakan asset lancer yang tersedia. Current Ratio (CR)menunjukkan kemampuan perusahaan dalam memenuhi kewajiban jangka pendek dengan menggunakan aktiva lancar. Semakin tinggi current ratio di suatu perusahaan berarti semakin baik perusahaan dalam memenuhi kewajiban jangka pendek akan tetapi currentratio yang tinggi juga menunjukkan kelebihan aktiva lancar yang tidak digunakan secara maksimal.

Return on equity (ROE) merupakan rasio yang menunjukkan hasil atas penggunaan ekuitas perusahaan dalam menciptakan laba bersih. Dengan kata lain rasio ini digunakan untuk mengukur seberapa besar jumlah laba bersih yang akan dihasilkan dari setiap rupiah dana yang tertanam dalam total ekuitas. Dengan kata lain, rasio ini digunakan untuk

mengukur seberapa besar jumlah laba bersih yang akan dihasilkan dari setiap rupiah dana yang tertanam dalam total ekuitas. Rasio ini dihitung dengan membagi laba bersih terhadap ekuitas. Debt to equity ratio merupakan rasio yang digunakan untuk menilai utang dengan ekuitas. Rasio ini dicari dengan cara membandingkan antara seluruh utang, termasuk utang lancer dengan seluruh ekuitas. Rasio ini berguna untuk mengetahui jumlah dana yang tersedia peminja (kreditor) denga pemilik perusahaan. Dengan kata lain, rasio ini berfungsi untuk mengetahui setiap rupiah modal sendiri yang dijadikan untuk jaminan utang. Debt to equity ratio merupakan rasio ini menunjukkan persentase penyediaan dana oleh pemegang saham terhadap pemberi pinjaman. Semakin tinggi rasio, semakin rendah pendanaan perusahaan yang disediakan oleh pemegang 


\section{RomlinaSianipar $^{1}$, Syahril Effendi ${ }^{2}$}

International Journal of Management and Business (IJMB)Vol.1 No.1 (2020) 88 - 97

saham [2]. Berdasarkan latar belakang di atas ,makadilakukanpenelitiandenganjudul"Pengaruh Rasio Keuangan Terhadap Return Saham Pada Perusahaan LQ45 Yang Terdaftar Di Bursa Efek Indonesia".

\section{KAJIAN PUSTAKA}

Saham merupakan salah satu instrumen pasar modal yang paling diminati investor karena memberikan tingkat keuntungan yang menarik [4]. Saham (stock) merupakan tanda penyertaan atau pemilikan seseorang atau badan dalam suatu perusahaan atau perseroan terbatas [4]. Saham berwujud selembar kertas yang menerangkan bahwa pemilik kertas tersebut adalah pemilik perusahaan yang menerbitkan surat berharga tersebut. Setiap saham yang dikeluarkan oleh perusahaan memiliki harga. Harga nominal saham adalah harga yang tercantum pada lembar saham yang diterbitkan.

Rasio yang paling umum digunakan untuk menganalisa posisi modal kerja suatu perusahaan adalah current ratio yaitu perbandingan antara jumlah aktiva lancer dengan hutang lancar. Rasio Lancar (Current Ratio) merupakan rasio untuk mengukur kemampuan perusahaan dalam memenuhi kewajiban jangka pendeknya yang segera jatuh tempo dengan menggunakan asset lancer yang tersedia. Return on equity (ROE) merupakan rasio yang menunjukkan hasil atas penggunaan ekuitas perusahaan dalam menciptakan laba bersih. Dengan kata lain rasio ini digunakan untuk mengukur seberapa besar jumlah laba bersih yang akan dihasilkan dari setiap rupiah dana yang tertanam dalam total ekuitas. Return on equity merupakan rasio yang digunakan untuk mengukurkemampuan dari modal sendiri untuk menghasilkan keuntungan bagiseluruh pemegang saham, baik saham biasa maupun saham preferen [6]. Return On Equity memiliki nilai yang rendah menunjukkan atau menggambarkan bahwa perusahaan kurang baik. Hal tersebut akan berdampak pada menurunnya tingkat pengembalian yang diinginkan pemegang saham, maka untuk memenuhi keinginan pemegang saham perusahaan harus melakukan pengembalian modal sesuai dengan jatuh tempo agar return on equity (ROE) tidak rendah. Hasil pengembalian atas ekuitas merupakan rasio yang menunjukkan seberapa besar konstribusi ekuitas dalam menciptakan laba bersih. Dengan kata lain, rasio ini digunakan untuk mengukur seberapa besar jumlah laba bersih yang akan dihasilkan dari setiap rupiah dana yang tertanam dalam total ekuitas. Rasio ini dihitung dengan membagi laba bersih terhadap ekuitas. Debt to equity ratio merupakan rasio yang digunakan untuk menilai utang dengan ekuitas. Rasio ini dicari dengan cara membandingkan antara seluruh utang, termasuk utang lancar dengan seluruh ekuitas. Rasio ini berguna untuk mengetahui jumlah dana yang tersedia peminja (kreditor) denga pemilik perusahaan. Dengan kata lain, rasio ini berfungsi untuk mengetahui setiap rupiah modal sendiri yang dijadikan untuk jaminan utang. Debt to equity ratio merupakan rasio ini menunjukkan persentase penyediaan dana oleh pemegang saham terhadap pemberi pinjaman. Semakin tinggi rasio, semakin rendah pendanaan perusahaan yang disediakan oleh pemegang saham [2]. Berikut penerlitian terdahulu yang menjadi panduan dalam penelitian ini: Berdasarkan penelitian yang dilakukan [7] dengan judul "Pengaruh Rasio Keuangan Terhadap Return Saham Pada Perusahaan Publik Manufaktur" di dapat hasil penelitian yang dilakukan oleh peneliti "rate of return on sales, asset turnover ratio dan earnings yield mempunyai pengaruh terhadap return saham. Hal ini menunjukan bahwa nilai return saham tergantung pada rate of return on sales, asset turnover ratio dan earnings yield Sedangkan current ratio, financial leverage, the proportion of profit margin before interest, tax and depreciation (EBITDM), working capital turnover, inventory turnover, the ratio of market value to book value of equity tidak memiliki pengaruh terhadap return saham". Berdasarkan penelitian yang dilakukan [8] dengan judul "Analisis Current Ratio, Return On Equity, Debt To Equity Ratio Dan Pertumbuhan Pendapatan Berpengaruh Terhadap Return Saham Pada Perusahaan Pertambangan Di Bursa Efek Indonesia 2010-2014" di dapat hasil penelitian yang dilakukan oleh peneliti sebagai berikut: a. Current Ratio (CR) tidak berpengaruh secara

Diterima Redaksi : 25-08-2020 | Selesai Revisi : 31-10-2020 | Diterbitkan Online : 20-11-2020 


\section{RomlinaSianipar $^{1}$, Syahril Effendi ${ }^{2}$}

International Journal of Management and Business (IJMB)Vol.1 No.1 (2020) 88 - 97

signifikan terhadap return saham, hal ini terjadi atas return saham PT. Adhi Karya ditunjukkan dari Thitung < Ttabel ($0,1292<2,021) \quad$ dan nilai signifikansi 0,8979>0,05. b. Return on Equity (ROE) tidak berpengaruh secara signifikan terhadap return saham, hal ini ditunjukkan dari Thitung $<$ Ttabel $(0.4786<2,021)$ dan nilai signifikansi $0,6352>$ 0,05. c. Debt to Equity Ratio (DER) tidak berpengaruh secara signifikan terhadap return saham, hal ini ditunjukkan dari thitung<ttabel $(0.6427<2,021)$ dan nilai signifikansi $0,5245>0,05$. d. Pertumbuhan pendapatan tidak berpengaruh signifikan terhadap return saham, hal ini ditunjukkan dari thitung $<$ ttabel $(1,0151<2,021)$ dan nilai signifikansi $0,3168>0,05$. e. Pada pengujian pengaruh Current Ratio (CR), Return on Equity (ROE), Debt to Equity Ratio (DER) dan pertumbuhan pendapatan secara simultan terhadap return saham, didapatkan hasil bahwa Current Ratio (CR), Return on Equity (ROE), Debt to Equity Ratio (DER) dan pertumbuhan pendapatan secara simultan berpengaruh signifikan terhadap return saham. Hal ini ditunjukkan nilai Fhitung $>$ Ftabel $(3,74>2,61)$ dengan nilai probabilitas (signifikansi) $0,0028<0,05$. Sedangkan besarnya pengaruh Current Ratio (CR), Return on Equity (ROE), Debt to Equity Ratio (DER) dan pertumbuhan pendapatan secara simultan terhadap Return Saham dapat dilihat dari nilai Adjusted R2 = 0,3328. Ini artinya Current Ratio (CR), Return on Equity (ROE), Debt to Equity Ratio (DER) dan pertumbuhan pendapatan berpengaruh secara simultan terhadap return saham sebesar 33,28\%. Sedangkan $66,72 \%$ yang lainnya dipengaruhi oleh variabel lain yang tidak ada dalam penelitian". Berdasarkan penelitian yang dilakukan [6] dengan judul "Analisis Pengaruh Rasio Keuangan terhadap Return Saham PT. Adhi Karya (Persero) Tbk" di dapat hasil penelitian rasio solvabilitas,dan rasio profitabilitas, memiliki pengaruh yang positif dan signifikan baik secara parsial maupun simultan terhadap return saham. Hasil analisis ini membuktikan kebenaran dari hipotesis pertama dan ketiga, tetapi menolak hipotesis kedua.Derajat korelasi maupun kemampuan menjelaskan dari ketiga variabel independen dalam model penelitian ini atas fluktuasi yang

(Persero) Tbk. juga relatif rendah".

Berdasarkan penelitian yang dilakukan [9] dengan judul "Pengaruh Return On Assets, Debt To Equity Ratio, Current Ratio, Earning Per Share Dan Nilai Tukar Terhadap Return Saham (Studi Kasus Pada Perusahaan Go Public Sektor Barang Konsumsi Yang Listing Di Bursa Efek Indonesia Periode 2015-2017)" di dapat hasil penelitian:Return On Assets (ROA) tidak berpengaruh terhadap return saham perusahaan Manufaktur Sektor Barang Konsumsi yang tedaftar di Bursa Efek Indonesia periode 20152017. Debt to Equity Ratio (DER) tidak berpengaruh terhadap return saham Perusahaan Manufaktur Sektor Barang Konsumsi yang tedaftar di Bursa Efek Indonesia periode 20152017. Current Ratio (CR) tidak berpengaruh terhadap return saham Perusahaan Manufaktur Sektor Barang Konsumsi yang tedaftar di Bursa Efek Indonesia periode 2015-2017. Earning Per Share (EPS) tidak berpengaruh terhadap return saham Perusahaan Manufaktur Sektor Barang Konsumsi yang tedaftar di Bursa Efek Indonesia periode 2015-2017. Nilai Tukar berpengaruh terhadap return saham Perusahaan Manufaktur Sektor Barang Konsumsi yang tedaftar di Bursa Efek Indonesia periode 2015-2017. Hasil uji F dalam penelitian ini menemukan bahwa ROA, DER, CR, EPS, dan Nilai Tukar secara simultan tidak berpengaruh terhadap return saham".

Berdasarkan penelitian yang dilakukan [10] dengan judul "Analisis Penerapan Sistem Informasi Akuntansi Dan Kualitas Laporan Keuangan UMKM Dalam Mengembangkan Bisnis Di Kota Batam" di dapat hasil penelitian: 1. Penerapan Sistem Informasi Akuntansi berpengaruh positif dan signifikan terhadap Pengembangan Bisnis di Kota Batam. 2. Kualitas Laporan Keuangan UMKM berpengaruh positif dan signifikan terhadap Pengembangan Bisnis di Kota Batam".

Berdasarkan penelitian yang dilakukan [11] dengan judul "Analisis Pengaruh Rasio Keuangan Terhadap Return Saham Perusahaan Manufaktur Yang Terdaftar Di Bursa Efek Indonesia Tahun 2016-2018" di dapat hasil penelitian: 1) Current ratio (CR) berpengaruh positif terhadap return saham perusahaan 


\section{RomlinaSianipar $^{1}$, Syahril Effendi ${ }^{2}$}

International Journal of Management and Business (IJMB)Vol.1 No.1 (2020) 88 - 97

manufaktur yang terdaftar di Bursa Efek Indonesia tahun 2016-2018. 2) Debt to equity ratio (DER) berpengaruh negatif terhadap return saham perusahaan manufaktur yang terdaftar di Bursa Efek Indonesia tahun 2016-2018. 3) Return on equity (ROE) berpengaruh positif terhadap return saham perusahaan manufaktur yang terdaftar di Bursa Efek Indonesia tahun 2016-2018. 4) Total assets turnover (TAT) tidak berpengaruh terhadap return saham perusahaan manufaktur yang terdaftar di Bursa Efek Indonesia tahun 2016-2018.

\section{METODE PENELITIAN}

Penelitian ini merupakan penelitian studi lapangan karena penelitian ini hanya mengumpulkan data, mencari fakta, kemudian menjelaskan data yaitu dengan cara pengumpulan dan penyunsunan data, selanjutnya dianalisis berdasarkanmodel analisis yang diambil dan kemudaian diinterpretasikan berdasarkan landasan teori yang ada. Jenis penelitian ini adalah penelitian kuantitatif yang bertujuan untuk menjelaskan suatu fenomena empiris yang disertai data statistik, karakteristik dan pola hubungan antarvariable. Penelitian kuantitatif penelitian yang bermula dari dari teori menuju data, dan berakhir pada penerimaan dan penolakan terhadap hipotesis yang digunakan sebagai cara untuk memecahkaan masalah yang diselidiki dengan mengambarkan keadaan subjek atau objek penelitian orang, lembaga, masyarakat pada saat sekarang berdasarkan fakta-fakta yang terlihat atau sebagaimana adanya. Penelitian kuntitatif dalam penelitian ini yang menganalisis dan untuk mengetahui adanya pengaruh antara variable Current Ratio (X1), Return on Equity (X2), Debt to Equity Ratio (X3), dan Return Saham (Y) di Bursa Efek Indonesia. Desain penelitian yang digunakan dalam penelitian ini adalah desain penelitian deskriptif. Variable independen adalah variable yang menjelaskan atau mempengaruhi variable yang lain. Variable bebas dalam penelitian ini adalah sebagai berikut :

\section{a. Current Ratio (X1)}

Rasio yang paling umum digunakan untuk menganalisa posisi modal kerja suatu perusahaan adalah current ratio yaitu perbandingan antara jumlah aktiva lancer dengan hutang lancar. Rasio Lancar (Current Ratio) merupakan rasio untuk mengukur kemampuan perusahaan dalam memenuhi kewajiban jangka pendeknya yang segera jatuh tempo dengan menggunakan asset lancer yang tersedia.

\section{b. Return on Equity (X2)}

Return on equity (ROE) merupakan rasio yang menunjukkan hasil atas penggunaan ekuitas perusahaan dalam menciptakan laba bersih. Dengan kata lain rasio ini digunakan untuk mengukur seberapa besar jumlah laba bersih yang akan dihasilkan dari setiap rupiah dana yang tertanam dalam total ekuitas. Hasil pengembalian atas ekuitas merupakan rasio yang menunjukkan seberapa besar konstribusi ekuitas dalam menciptakan laba bersih. Dengan kata lain, rasio ini digunakan untuk mengukur seberapa besar jumlah laba bersih yang akan dihasilkan dari setiap rupiah dana yang tertanam dalam total ekuitas. Rasio ini dihitung dengan membagi laba bersih terhadap ekuitas.

\section{c. Debt to Equity Ratio (X3)}

Debt to equity ratio merupakan rasio yang digunakan untuk menilai utang dengan ekuitas. Rasio ini dicari dengan cara membandingkan antara seluruh utang, termasuk utang lancar dengan seluruh ekuitas. Rasio ini berguna untuk mengetahui jumlah dana yang tersedia peminja (kreditor) denga pemilik perusahaan. Dengan kata lain, rasio ini berfungsi untuk mengetahui setiap rupiah modal sendiri yang dijadikan untuk jaminan utang.

Debt to equity ratio merupakan rasio ini menunjukkan persentase penyediaan dana oleh pemegang saham terhadap pemberi pinjaman. Semakin tinggi rasio, semakin rendah pendanaan perusahaan yang disediakan oleh pemegang saham [2].

Variabel dependen (terikat) adalah variable yang dijelaskan atau yang dipengaruhi oleh variable independen dalam penelitian ini 


\section{RomlinaSianipar $^{1}$, Syahril Effendi ${ }^{2}$}

International Journal of Management and Business (IJMB)Vol.1 No.1 (2020) 88 - 97

penulis mengambil variable terikat (variable dependen) adalah return Saham.

\section{a. Return Saham (Y)}

Saham (stock) merupakan tanda penyertaan atau pemilikan seseorang atau badan dalam suatu perusahaan atau perseroan terbatas [4]. Saham berwujud selembar kertas yang menerangkan bahwa pemilik kertas tersebut adalah pemilik perusahaan yang menerbitkan surat berharga tersebut. Setiap saham yang dikeluarkan oleh perusahaan memiliki harga. Harga nominal saham adalah harga yang tercantum pada lembar saham yang diterbitkan Populasi adalahwilayah generalisasi yang terdiri atas objek/subjek yang mempunyai kualitas dan karakteristik tertentu yang ditetapkan oleh peneliti untuk dipelajari dan kemudian ditarik kesimpulannya. Adapun populasi dalam penelitian ini adalah data Current Ratio, Return on Equity, Debt to Equity Ratio, dan Return Saham pada perusaahaan LQ45 yang terdaftar di Bursa Efek Indonesia selama 5 tahun dari tahun 2015-2019. Sampel adalah sebagian unit populasi yang menjadi objek penelitian untuk memperkirakan karakteristik suatu populasi. Teknik sampling yang digunakan adalah teknik sampling jenuh yaitu teknik penentuan sampel apabila semua anggota populasi digunakan sebagai sampel.Adapun sampel dalam penelitian ini adalah perusahaan LQ45 yang terdaftar di bursa Efek Indonesia Exchange Stock (IDX). Metodeanalisisdatamerupakanmetodeyangdi gunakanuntukmengolah dan memprediksi hasil penelitian guna memperoleh suatu kesimpulan. Berdasarkan judul, latarbelakang, danperumusan masalah maka teknik analisis data yang digunakan adalah analisis regresi linear berganda yang bertujuan untuk mengukur kekuatan asosiasi (hubungan) linear antara dua variabel atau lebih. Penelitian dengan menggunakan model regresi membutuhkan beberapa pengujian asumsi klasik untuk mengetahui apakah hasil estimasi regresi yang dilakukan benar-benar bebas dari adanya gejala multikolinearitas. Uji normalitas adalah model regresi yang digunakan untukmenguji apakah nilai residual terdistribusi secara normal atau tidak. Model regresi yang baik adalah memiliki distribusi data normal atau mendekati normal. Untuk mendeteksi normalitas data, dapat dilakukan dengan uji Kolmogorov-Smirnov dannormal probability plot. Multikolineritas berarti terjadi korelasi linear yang mendekati sempurna antar dua variabel bebas.Uji multikolineritas bertujuan untuk menguji apakah dalam model regresi yang terbentuk ada korelasi yang tinggi atau sempurna diantara variabel bebas atau tidak. Jika dalam model regresi yang terbentuk terdapat korelasi yang tinggi atau sempurna diantara variabel bebas maka model regresi tersebut dinyatakan mengandung gejala multikolinier.UjiHeteroskedastisitas

bertujuan menguji apakah dalam model regresi terjadi ketidaksamaan variance dari residual yaitu pengamatan ke pengamatan yang lain. Uji Autokorelasi adalah korelasi (hubungan) yang terjadi diantara anggotaanggota dari serangkaianpengamatan yang tersusun dalam rangkaian waktu (seperti pada data runtun waktu atau time series data) atau yang tersusun dalam rangkaian ruang (seperti pada data silang waktu atau crosssectional data). Uji Tdi gunakan untuk menguji signifikan pengaruhvaribel independen terhadap variabel dependen secara individual dalam menerangkan variasi variabel dependen. UjiF digunakan untuk menguji apakah semua variabel independen yang dimasukkan dalam model mempunyai pengaruh secara bersama-sama terhadap variabel dependen.

\section{HASIL DAN PEMBAHASAN Analisis Deskriptif}

Dari table 4.1 diatas dapat dilihat jumlah sampel (N) sebanyak 45 sampel yang terdiri dari data time series tahun yang telah berjalan sebanyak 5 tahun, yaitu dari 2015 sampai dengan 2019. Berdasarkan tabel 4.1 diatas Current Ratio memiliki nilai nilai minimum -66,24, nilai maximum224,09, nilai mean 49,12, dan standar deviasinya 
RomlinaSianipar ${ }^{1}$, Syahril Effendi ${ }^{2}$

International Journal of Management and Business (IJMB)Vol.1 No.1 (2020) 88 - 97

sebesar 50,765. Return on Equity memiliki 388,83, nilai mean 111,9682, dan standar nilaiminimum 7,66 , nilai maximum 332 , nilai mean 62,835 , dan standar deviasinya sebesar 49,4605. Debt to Equity Ratio memiliki nilaiminimum 1,01 , nilai maximum deviasinya sebesar 105,9235. Return Saham memiliki nilaiminimum 1,04 , nilai maximum 350,07, nilai mean 99,3571, dan standar deviasinya sebesar 103,3231.

Tabel 1Statistik Deskriptif

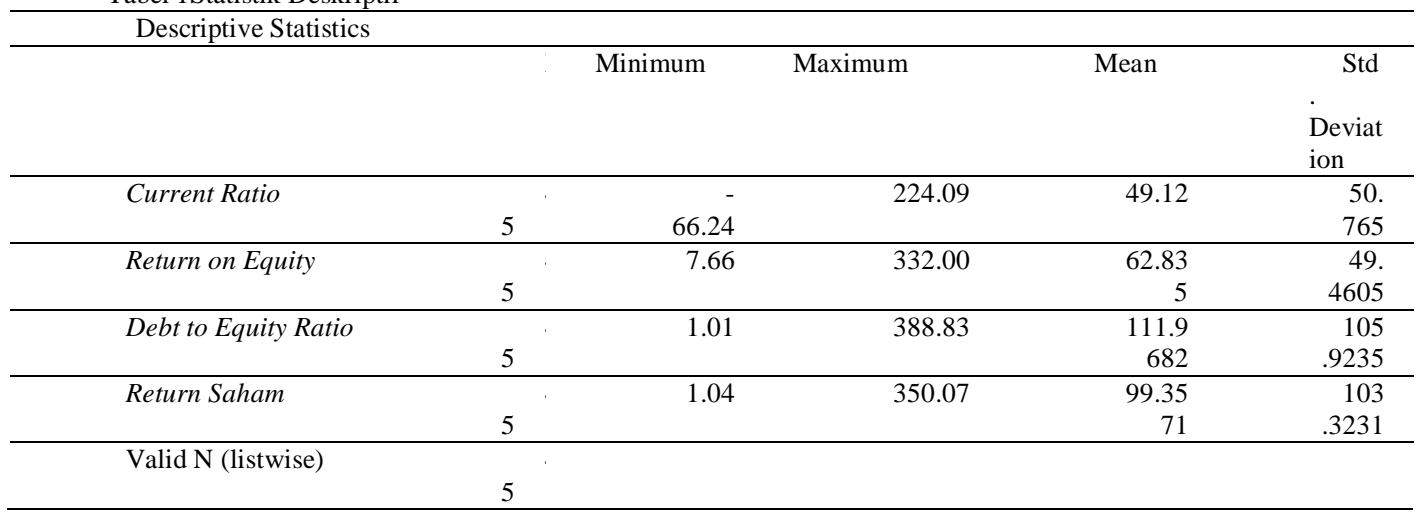

Diterima Redaksi : 25-08-2020 | Selesai Revisi : 31-10-2020 | Diterbitkan Online : 20-11-2020 


\section{Uji Normalitas}

pengujian normalitas dilakukan untuk mengetahui apakah variable-variabel dalam penelitian berdistribusi dengan normal atau tidak.Model regresi yang baik adalah data yang berdistribusi dengan normal.Dalam pengujian normalitas ini, penulis menggunakan pengujian dengan melihat hasil grafik normal probality plot. Apabila gambar histogram berbentuk kurva yang menyerupai lonceng (Bell Shape) maka model berdistribusi normal. Dan bila gambar grafik pada Normal P-P Plot keberadaan titiktitik berada di sekitar garis, maka model berdistribusi normal.

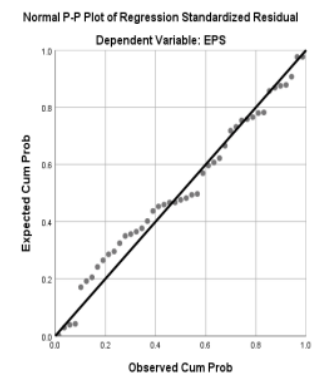

Gambar 1. Uji Normalitas

Berdasarkan gambar dibawah maka dapat diambil kesimpulan bahwa model memiliki distribusi normal, hal ini dapat diperlihatkan oleh bentuk kurva yang menyerupai lonceng (Bell Shaped).

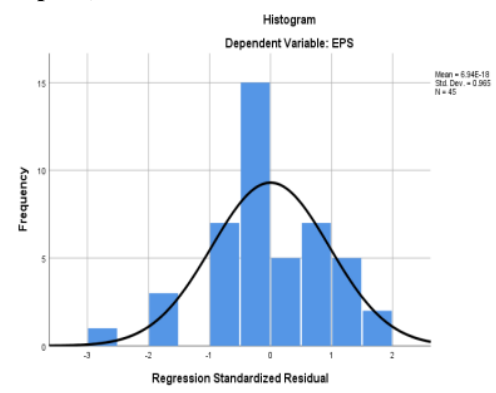

Gambar 2. Histogram Uji Normalitas

Berdasarkan perhitungan table 1 diatas, nilai Asymp. Sig. (2-tailed)dalam Uji Kolmogorovsmirnov menunjukkan nilai probalitas $0,100>$ 0,05 atau $5 \%$ yang berarti penelitian ini normalitas.

Tabel 2 One Sample Kolmogorov Smirnov

\begin{tabular}{c} 
One-Sample Kolmogorov-Smirnov Test \\
\hline Unstandardized \\
Residual
\end{tabular}

\begin{tabular}{|c|c|c|}
\hline $\mathrm{N}$ & & 180 \\
\hline \multirow{4}{*}{$\begin{array}{l}\text { Normal } \\
\text { Parameters }\end{array}$} & Mean & ,000000 \\
\hline & & 0 \\
\hline & Std. & 78,2164 \\
\hline & Deviation & 8923 \\
\hline \multirow{5}{*}{$\begin{array}{l}\text { Most Extreme } \\
\text { Differene }\end{array}$} & Absol & ,244 \\
\hline & ute & \\
\hline & Positi & ,244 \\
\hline & ve & \\
\hline & Negat &,- 189 \\
\hline \multicolumn{2}{|c|}{ Asymp. Sig. (2-tailed) } &, $100^{\mathrm{c}}$ \\
\hline
\end{tabular}

Uji Multikolinieritas

Tabel 3Uji Multikolinieritas

Coefficients $^{\mathrm{a}}$

Model

Collinearity

Statistics

\begin{tabular}{lcc} 
& \multicolumn{2}{c}{ Statistics } \\
\cline { 2 - 3 } & Tole & \\
& rance & IF \\
\hline t) (Constan & & \\
\hline Current Ratio & .784 & .275 \\
\hline Return on Equity & .888 & .127 \\
\hline Deb to Equity Ratio & .854 & .170 \\
\hline
\end{tabular}

\section{Uji Heterokedastisitas}

Pada grafik dibawah dapat dilihat bahwa titik-titik menyebar secara acak serta tersebar baik diatas maupun dibawah angka 0 (nol) pada sumbu Y, hal ini dapat disimpulkan tidak terjadi heteroskedastisitas pada model regresi ini.

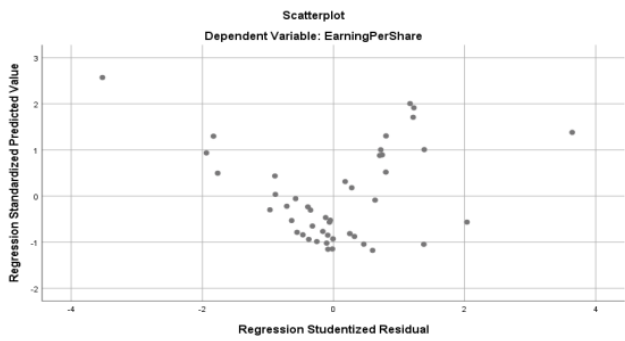

Gambar 3. Uji Heterokedastisitas

Uji Autokorelasi

Diterima Redaksi : 25-08-2020 | Selesai Revisi : 31-10-2020 | Diterbitkan Online : 20-11-2020 
Jika probabilitas nilai Durbin-Watson adalah 1,364>0,05maka dapat dikatakan bahwa suatu model dapat dinyatakan tidak terjadi gejala autokorelasi.

Tabel 4 Uji Autokorelas

\begin{tabular}{rrrr}
\hline & \multicolumn{2}{c}{ Adjusted } & $\begin{array}{c}\text { Durb } \\
\text { in-Watson }\end{array}$ \\
\hline & R Square & R Square & 1.364 \\
717 & .5 & .479 & \\
\hline
\end{tabular}

Tabel 5 Analisis Linier Berganda

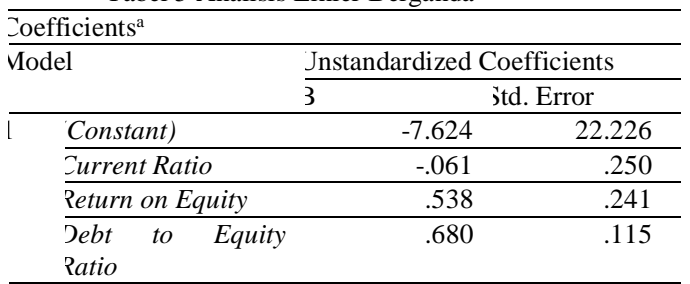

1. Konstan (a) sebesar 101,124 artinya bahwa apabila variabel independen yaitu Current Ratio, Return on Equit, dan Debt to Equity dianggap konstan (bernilai 0) maka diprediksi variabel terikat Return Saham berjumlah sebesar -7,624.

2. Variabel X1 Current Ratio memiliki nilai koefisien regresi sebesar $-0,061$.

3. Variabel X2 Return on Equity memiliki nilai koefisien regresi sebesar 0,538.

4. Variabel X3 Debt to Equity Ratio memiliki nilai koefisien regresi sebesar 0,680.

Uji T

Tabel 6.Uji T

\begin{tabular}{crc} 
Tabel 6.Uji T & & \\
\hline Coefficients $^{\mathrm{a}}$ & $\mathrm{T}$ & $\mathrm{i}$ \\
\hline Model & & $\mathrm{g}$ \\
& & $\cdot$ \\
& & \\
\hline (Constant) & - & \\
& .343 & 7 \\
& & 3 \\
& & 3 \\
\hline Current Ratio & - & \\
& .242 & 8 \\
& & 1 \\
\hline Return on Equity & 2 & 0 \\
\hline & .232 & 0 \\
\hline
\end{tabular}

\begin{tabular}{lrl}
\hline & & 1 \\
\hline Debt to Equity Ratio & 5 & \\
& .923 & 0 \\
& 0 \\
& 0
\end{tabular}

\section{Uji F}

Tabel 7 Hasil Uji F

ANOVA $^{\mathrm{a}}$

Model

$\mathrm{F}$

$\mathrm{S}$

ig.

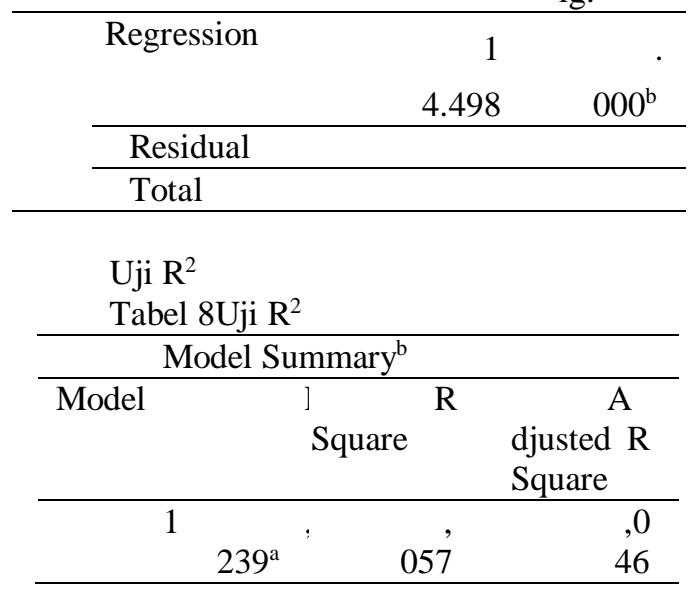

Pengaruh Current Ratio Terhadap Return

Saham

Bedasarkan hasil pengujian hipotesis mengenai

Current Ratio terhadap Return Saham menunjukkan nilai $0,242>$ nilai $t_{\text {tabel }} 2,016$ dengan angka signifikasi 0,810 >0,05. Dengan demikian dapat disimpulkan bahwa variabel current ratio tidakberpengaruh signifikan terhadap return saham.

Pengaruh Return on Equity Terhadap Return Saham

Bedasarkan hasil Uji $\mathrm{T}$ pengujian hipotesis mengenai Return on Equity berpengaruh signifikan terhadap Return Saham. Dari hasil pengujian variabel diatas, Return on Equity menunjukkan bahwa nilai $t_{\text {hitung }}$ sebesar 2,232> nilai $t_{\text {tabel }}$ sebesar 2,016 dengan angka signifikasi sebesar 0,031>0,05.

Pengaruh Debt to Equity Ratio Terhadap Return Saham

Bedasarkan hasil Uji $\mathrm{T}$ pengujian hipotesis mengenai Debt to Equity Ratio berpengaruh signifikan terhadap Return Saham. Dari hasil pengujian variabel diatas, Debt to Equity Ratio

Diterima Redaksi : 25-08-2020 | Selesai Revisi : 31-10-2020 | Diterbitkan Online : 20-11-2020 
menunjukkan bahwa nilai thitung sebesar 5,923 > nilai $t_{\text {tabel }}$ sebesar 2,016 dengan angka signifikasi sebesar $0,000>0,05$.

\section{Pengaruh Current Ratio, Return on Equity,} dan Debt to Ratio Terhadap Return Saham

Berdasarkan hasil pengujian, nilai $F$ menunjukkkan bahwa nilai signifikan sebesar $0,000<0,05$ dan $F_{\text {hitung }}>F_{\text {tabel, dimana nilai }}$ $F_{\text {hitung }} 14,498>F_{\text {tabel }}$ sebesar 3,21 maka hipotesis yang menyatakan Current Ratio, Return on Equity, dan Debt to Ratiosecara bersama-sama berpengaruh signifikan terhadap Return Saham.

\section{Kesimpulan}

Kesimpulan dari hasil penelitian ini sebagai berikut:

a. Current Ratio tidak berpengaruh signifikan terhadap Return Saham. Dari hasil pengujian variabel diatas, berdasarkan Tabel 4.6 hasil uji $\mathrm{T}$ menunjukkan nilai $\mathrm{T}_{\text {hitung }} 0,242>$ nilai $\mathrm{T}_{\text {tabel }}$ 2,016 dengan angka signifikasi $0,810<0,05$.

b. Return on Equity berpengaruh terhadap Return Saham. Dari hasil pengujian variabel diatas, berdasarkan Tabel 4.6 hasil uji $\mathrm{T}$ menunjukkan bahwa nilai $\mathrm{T}_{\text {hitung }}$ sebesar 2,232> nilai $\mathrm{T}_{\text {tabel }}$ sebesar 2,016 dengan angka signifikasi sebesar $0,031>0,05$.

c. Debt to Equity Ratio berpengaruh terhadap Return Saham. Dari hasil pengujian variabel diatas, berdasarkan Tabel 4.6 hasil uji T menunjukkan bahwa nilai $\mathrm{T}_{\text {hitung }}$ sebesar $5,923<$ nilai $\mathrm{T}_{\text {tabel }}$ sebesar 2,016 dengan angka signifikasi sebesar $0,000>0,05$.

d. Current Ratio, Return on Equity, dan Debt to Equity Ratio secara bersamasama berpengaruh signifikan terhadap Return Saham. Berdasarkan tabel dapat disimpulkan hasil uji $\mathrm{F}$ menunjukkkan bahwa nilai signifikan sebesar $0,000<$
0,05 dan $F_{\text {hitung }}>F_{\text {tabel, }}$ dimana nilai $F_{\text {hitung }}$ $14,498>F_{\text {tabel }}$ sebesar 3,21.

\section{Daftar Rujukan}

[1] Hery, Analisis Laporan Keuangan. Kompas Gramedia, 2018.

[2] F. E. Septiana, "Pengaruh Rasio Keuangan Terhadap Return Saham Pada Perusahaan Manufaktur," ISSN 2461-0593, vol. 5, no. 1, pp. 121, 2016.

[3] D. Kasmir, Analisis Laporan Keuangan, 11th ed. Depok: PT Rajagrafindo Persada, 2019.

[4] P. Akri and Antoni, "Pengaruh Rasio Keuangan Terhadap Return Saham Sektor Pertanian Di Bursa Efek Indonesia Tahun 2010 - 2016," ISSN 2527 8215, vol. 3, no. 2, pp. 171-182, 2018.

[5] D. S. Munawir, Analisis Laporan Keuangan, 4th ed. Yogyakarta: Liberty Yogyakarta, 2019.

[6] M. Fuad and N. Al Mughni, "Analisis Pengaruh Rasio Keuangan terhadap Return Saham PT. Adhi Karya (Persero) Tbk.," J. Samudra Ekon. dan Bisnis, vol. 9, no. 2, pp. 116-127, 2018.

[7] J. Trisca and Mungniyati, "Pengaruh Rasio Keuangan terhadap Return Saham pada Perusahaan Manufaktur," ISSN 1410-9875, vol. 19, no. 1, pp. 1689-1699, 2017.

[8] I. Nurmasari, "Analisis Current Ratio, Return On Equity, Debt To Equity Ratio, Dan Pertumbuhan Pendapatan Berpengaruh Terhadap Return Saham Pada Perusahaan Pertambangan Di BEI," ISSN 2339-0689, vol. 5, no. 1, pp. 112-131, 2017.

[9] N. Supriantikasari and E. S. Utami, "Pengaruh Return On Assets, Debt To Equity Ratio, Current Ratio , Earning Per Share Dan Nilai Tukar Terhadap Return Saham ( Studi Kasus Pada Perusahaan Go Public Sektor Barang Konsumsi Yang Listing Di Bursa Efek Indonesia Periode 2015-2017 )," ISSN 2460-1233, vol. 5, no. 1, pp. 49-66, 2019.

[10] S. Effendi and B. Harahap, "Analisis Penerapan Sistem Informasi Akuntansi Dan Kualitas Laporan Keuangan Umkm Dalam Mengembangkan Bisnis Di Kota Batam,” J. Akunt. Barelang, vol. 4, no. 1, pp. 123-131, 2019.

[11] P. S. Indiyani, N. M. Sunarsih, and I. A. N. Yuliastiti, "Analisis Pengaruh Rasio Keuangan Terhadap Return Saham Perusahaan Manufaktur Yang Terdaftar Di Bursa Efek Indonesia Tahun 2016-2018," ISSN 1978-6069, vol. 15, no. 1, 2020.

[12] Sugiyono, Metode Penelitian Kuantitatif, Kualitatif, Dan $R \& D$, Keenambela. Bandung: Alfabeta, 2012.

[13] I. Ghozali, Aplikasi Analisis Multivariete, 